\title{
KARAKTERISTIK BALOK LAMINASI KAYU AKASIA (Acacia Mangium) DAN MERANTI MERAH (Shorea leprosula) BERDASARKAN SUSUNAN LAMINA DAN BERAT LABUR PEREKAT STYROFOAM
}

\section{(Characteristics of Glued Laminated Timber of Acacia mangium and Shorea leprosula Based on Laminated Structure and Glue Spread Styrofoam adhesive)}

\author{
Sonia Somadona ${ }^{1}$, Evi Sribudiani ${ }^{1}$, Ditiya Elsa Valencia ${ }^{2}$ \\ 1 Staff Pengajar Jurusan Kehutanan, Fakultas Pertanian Universitas \\ 2 Jurusan Kehutanan, Fakultas Pertanian Universitas Riau Riau
}

Jln. Kampus Bina Widya KM. 12,5, Simpang Baru, Kec. Tampan, Kota Pekanbaru, Riau 28293

E-mail:, sonia_hut@yahoo.co.id, sribudiani_unri@yahoo.co.iddanditiyaelsavelencia07@gmail.com

Diterima: 30 September 2020, Direvisi: 05 Oktober 2020, Disetujui: 25 November 2020

DOI: $10.31849 /$ forestra.v15i2.5039

\begin{abstract}
The potential for wood raw materials in Indonesia is very abundant, but the increasing need for processed wood as a building material makes it difficult to obtain sawn timber in large sizes and with quality, due to the increasingly limiting logging in natural forests. High quality wood is hard to find in the market, so it is necessary to combine low quality and high quality wood by engineering the product with an adhesive, one of which is glued laminated timber. This study aims to see the characteristics of the glued laminated timber of Acacia mangium and Shorea leprosula based on the arrangement of lamina and the weight of adhesive Styrofoam. The size og glulam in this study were $120 \mathrm{~cm} \times 5 \mathrm{~cm} \times 3 \mathrm{~cm}$ with six layer and the adhesive composition used was 60\% Styrofoam and 40\% gasoline with an glue spread of 200, 220 and $240 \mathrm{gr} / \mathrm{m}^{2}$. Observations made to produce data that is, the moisture content obtained layer ranged from 4.14 to $8.86 \%$, a density of 0.38 to $0.51 \mathrm{~g} / \mathrm{cm}^{3,}$ MOE range from 823,87 -2975,05 $\mathrm{kg} / \mathrm{cm}^{2}$ and MOR ranged from 24.78 to $86.71 \mathrm{~kg} / \mathrm{cm}^{2}$. This board is suitable for vertical applications only such as dividers and door fillers.
\end{abstract}

Keywords: Wood, Lamina Block, Styrofoam

\begin{abstract}
ABSTRAK
Potensi bahan baku kayu di Indonesia sangat melimpah, akan tetapi meningkatnya kebutuhan akan kayu olahan sebagai bahan bangunan menyebabkan sulit untuk memperoleh kayu gergajian dalam ukuran besar dan berkualitas, karena semakin dibatasinya penebangan di hutan alam. Kayu dengan kualitas tinggi sulit ditemukan di pasaran sehingga perlunya upaya menggabungkan kayu kualitas rendah dan kualitas tinggi dengan cara rekayasa produk dengan perekat salah satunya balok laminasi. Penelitian
\end{abstract}

Sonia Somadona, Evi Sribudiani, Ditiya Elsa V/Wahana Forestra: Jurnal Kehutanan Vol 15 No 02/2020 53 
ini bertujuan untuk melihat karakteristik dari balok laminasi kayu akasia (Acacia mangium) dan meranti merah (Shorea leprosula) berdasarkan susunan lamina dan berat labur perekat Styrofoam. Balok laminasi yang dibuat berukuran $120 \mathrm{~cm}$ x $5 \mathrm{~cm}$ x 18 dengan masing-masing jumlah lapisan 6 lapis dan dengan komposisi perekat yang digunakan adalah $60 \%$ Styrofoam dan $40 \%$ pertalite dengan berat labur perekatnya 200, 220 dan $240 \mathrm{gr} / \mathrm{m}^{2}$. Pengamatan yang dilakukan menghasilkan data yaitu, kadar air yang didapatkan lapisan berkisar antara 4,14-8,86 \%, nilai kerapatan $0,38-0,51 \mathrm{gr} / \mathrm{cm}^{3}$, nilai MOE 23,87 $2975,05 \mathrm{~kg} / \mathrm{cm}^{2}$ dan MOR berkisar 24,78-86,71 kg/ $\mathrm{cm}^{2}$. Papan ini hanya cocok dalam penggunaan keperluan vertikal saja seperti penyekat, dan pengisi pintu rumah.

Kata kunci: Kayu, Balok Lamina, perekat, Styrofoam

\section{PENDAHULUAN}

Akasia merupakan salah satu tanaman yang cepat tumbuh (fast growing spesies) dan mudah tumbuh (adapitve) pada kondisi lahan yang tingkat kesubururannya rendah. Pusat Penelitian dan Pengembangan Hasil Hutan (2008) menyebutkan bahwa berat jenis ratarata kayu akasia adalah 0,5 (0,46-0,52) dengan kelas kuat III. Kayu ini bisa digunakan sebagai bahan bangunan namun perlu ditingkatkan kualitasnya.

Upaya untuk meningkatkan kualitas kayu Akasia adalah dengan cara rekayasa teknologi dengan menggabungkan kayu kualitas rendah dengan kayu kualitas tinggi yaitu dengan membuat balok laminasi. Balok lamina adalah balok yang diperoleh dari hasil perekatan papan tipis yang disusun sejajar serat menggunakan perekat. Balok laminasi lebih efisien dibandingkan kayu utuh karena dapat dibuat dengan menggabungkan jenis kayu bermutu rendah dan kayu bermutu tinggi (Abdurrachman dan Hadjib, 2005). Salah satu jenis kayu berkerapatan tinggi dan bisa digunakan pelapis kayu akasia untuk meningkatkan kualitasnya adalah kayu meranti merah.

Meranti merah tergolong kayu keras berbobot ringan, sedang sampai berat. Memiliki tekstur agak kasar. Berat jenisnya berkisar antara 0,3-0,86 dengan kelas kuat IIIV, sedangkan keawetannya tergolong dalam kelas III-IV. Kayu meranti merah merupakan kayu berharga yang banyak digunakan untuk berbagai keperluan seperti kayu lapis, kayu gergajian, dan bahan bangunan. Selain itu, kayu meranti merah juga digunakan untuk konstruksi berat atau sedang, balok, kaso, kusen pintu-pintu dan jendela, papan lantai, 
geladak jembatan, serta untuk membuat perahu (Irwanto, 2009 dalam Kusuma, 2014).

Faktor lain yang berpengaruh terhadap kualitas kayu laminasi adalah berat labur perekat. Pada penelitian ini perekat yang digunakan adalah perekat polystyrene berupa stayrofoam. Styrofoam merupakan salah satu olahan dari polystyrene yang merupakan bentukan senyawa styrene yang menggunakan benzena dalam pengolahannya (Winarno, 2015).

Styrofoam merupakan salah satu jenis polimer plastik yang memiliki sifat termoplastik, yaitu menjadi lunak jika dipanaskan dan mengeras kembali setelah dingin. Selain itu Styrofoam juga memiliki sifat tahan terhadap asam, basa dan sifat korosif lainnya. Memanfaatkan limbah Styrofoam sebagai perekat akan mendukung gerakan ramah lingkungan karena dapat mengurangi pencemaran lingkungan.

Berdasarkan perlu dilakukannya pengujian karakteristik balok laminasi yang dibuat, sehingga perlu dilakukan penelitian dengan judul "Karakteristik Balok Laminasi Kayu Akasia (Acacia mangium) dan Meranti Merah (Shorea leprosula Miq.) Berdasarkan
Susunan Lamina Dan Berat Labur Perekat Styrofoam".

Tujuan dari penelitian ini adalah untuk mengetahui karakteristik dari balok laminasi kayu akasia dan meranti merah berdasarkan susunan lamina dan berat labur perekat Styrofoam.

\section{METODE PENELITIAN}

Penelitian ini dilakasanakan di Laburatorium Kehutanan Fakultas Pertanian, Universitas Riau. Penilitian dilaksanakan selama delapan bulan dari bulan Maret 2019 hingga Oktober 2019.

Bahan yang digunakan dalam penelitian ini adalah kayu akasia dengan kerapatan berkisar 0,3-0,4 gr/ $\mathrm{cm}^{3}$, kayu meranti merah dengan kerapatan berkisar 0,4-0,6 $\mathrm{gr} / \mathrm{cm}^{3}$. Styrofoam bungkus makanan, dan pertalite.

Alat yang digunakan adalah timbangan analitik, oven, kantong plastik, pengaduk, gergaji, gelas ukur, kertas ampelas, alat kempa/klem, UTM (Universal Testing Machine), kaliper, penggaris, alat hitung, dan alat tulis. 
Pelaksaan penelitian dilakukan dengan beberapa tahap yaitu;

\section{a. Persiapan Pengambilan Bahan dan Pembuatan Contoh Uji}

Bahan penelitian berupa kayu akasia dan meranti merah berasal dari panglong, dan Styrofoam berasal dari limbah yang tidak terpakai. Bahan penelitian berupa kayu akasia dan meranti merah memiliki ukuran $120 \mathrm{~cm} \mathrm{x}$ $5 \mathrm{~cm}$ x $3 \mathrm{~cm}$. Papan-papan tersebut kemudian dikering anginkan hingga mencapai kadar air $12 \%-18 \%$.

Bahan penelitian berupa Styrofoam tempat makanan dijarang menjadi potonganpotongan kecil. Kemudian dicampurkan dengan pertalite untuk meleburkan Styrofoam, yang nantinya akan dijadikan sebagai perekat. Selanjutnya dilakukan pembuatan papan lamina sesuai dengan prosedur kerja.

\section{b. Pembuatan Perekat}

Perekat dibuat dengan melarutkan Styrofoam menggunakan pertalite. Perekat dibuat dengan komposisi $60 \%$ Styrofoam dan $40 \%$ pertalite. Proses pembuatan perekat dari campuran Styrofoam dan pertalite sebagai berikut :

1. Tuang pertalite pada wadah yang telah disediakan.

2. Potong / rajang Styrofoam menjadi bagian yang kecil-kecil agar mudah ketika dicampur dengan pertalite pada wadah.

3. Campur pertalite dan Styrofoam menggunakan alat pengaduk dengan perlahan.

4. Setelah semua tercampur akan menjadi pasta yang kental

\section{c. Penyusunan dan Perekatan Lamina}

Balok laminasi yang dibuat terdiri dari 6 lapisan dengan susunan lamina sebagai berikut :

$$
\begin{aligned}
\mathrm{P}_{1}= & \text { akasia }- \text { akasia }- \text { akasia }- \text { akasia }- \\
& \text { akasia }- \text { akasia } \\
\mathrm{P}_{2}= & \text { meranti merah }- \text { meranti merah - } \\
& \text { meranti merah }- \text { meranti merah - } \\
& \text { meranti merah }- \text { meranti merah } \\
\mathrm{P}_{3}= & \text { akasia }- \text { akasia }- \text { meranti merah - } \\
& \text { meranti merah }- \text { akasia }- \text { akasia }
\end{aligned}
$$


$\mathrm{P}_{4}=$ akasia - meranti merah - meranti merah - meranti merah - meranti merah- akasia

$\mathrm{P}_{5}=$ meranti merah - meranti merah akasia - akasia - meranti merahmeranti merah $\mathrm{P}_{6}=$ meranti merah - akasia - akasia akasia - akasia - meranti merah

Kemudian lamina-lamina direkatkan menggunakan perekat Styrofoam dengan berat labor yaitu sebesar $200 \mathrm{gr} / \mathrm{m}^{2}$ (A1), 220 $\mathrm{gr} / \mathrm{m}^{2}$ (A2) dan $240 \mathrm{gr} / \mathrm{m}^{2}$ (A3), dengan masing-masing perlakukan dibuat 3 ulangan.

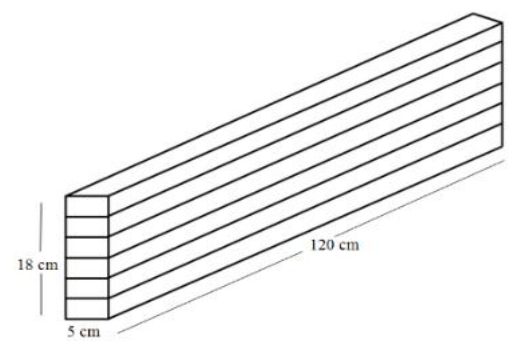

\section{Gambar 1. Contoh uji}

\section{d. Pengempaan}

Proses pengempaan balok laminasi mengacu pada prosedur penelitian yang dilakukan oleh Sari (2011) dimana Pengempaan dilakukan dengan cara menempatkan lamina yang telah diberi perekat pada plat kempa kemudian dilakukan penekanan dengan tekanan sebesar 8 - 14 $\mathrm{kg} / \mathrm{cm}^{2}$. Lamanya waktu pengempaan adalah 24 jam pada suhu ruangan.

\section{e. Pengkondisian}

Proses pengkondisian balok laminasi mengacu pada prosedur penelitian yang dilakukan oleh Sari (2011) dimana Balok laminasi hasil pengempaan dingin ditempatkan di ruangan terbuka selama satu minggu. Penyerutan balok laminasi dilakukan untuk membersihkan perekat sisa yang dihasilkan dari proses pengempaan dan pemotongan sisi maupun pemotongan ujung balok laminasi untuk mendapatkan ukuran yang diinginkan.

\section{f. Pola Pemotongan Sampel}

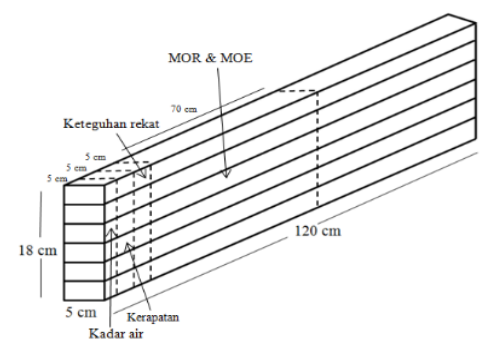

Gambar 2. Pola pemotongan sampel 


\section{g. Pengujian Sifat Fisis dan Mekanis Balok Laminasi}

Sifat fisis yang diuji meliputi uji kadar air dan berat jenis. Sedangkan sifat mekanis yang diuji adalah kekuatan lentur (MOE), keteguhan lengkung (MOR) dan keteguhan geser. Pengujian sifat fisis dan mekanis balok laminasi mengacu pada JAS 234 : 2003.

Tabel 1. Standar Balok Laminasi JAS 234 : 2003

\begin{tabular}{llll}
\hline Sifat fisis dan mekanis & Standar JAS & 234 & : \\
& 2003 & & \\
\hline Kadar air & $15 \%$ & & \\
Kerapatan & - & & \\
MOE & $75 \times 10^{3} \mathrm{~kg} / \mathrm{cm}^{2}$ & \\
MOR & $300 \mathrm{~kg} / \mathrm{cm}^{2}$ & \\
\hline
\end{tabular}

\section{Kadar Air}

Pengujian kadar air balok laminasi dilakukan dengan mengacu pada Sari (2011) dimana pengujian kadar air dilakukan menggunakan contoh uji yang dipotong sepanjang $5 \times 5 \times 5 \mathrm{~cm}$ dari bagian balok laminasi. Jumlah contoh uji yang digunakan sebanyak empat ulangan untuk setiap jenis balok laminasi. Potongan balok lamina tersebut ditimbang pada suhu kering udara untuk mengetahui berat awal kering udara (BA). Contoh uji kemudian dimasukkan ke dalam oven dengan suhu $\left(103+2{ }^{\circ} \mathrm{C}\right)$ selama 12 jam, selanjutnya akan ditimbang kembali dan didapat berat kering sampel (BKT).

Persamaan perhitungan kadar air dapat ditulis sebagai berikut :

\section{Kerapatan}

$$
K A(\%)=\frac{B A-B K T}{B K T} \times 100 \%
$$

Kerapatan dihitung dengan menggunakan contoh uji dari setiap balok laminasi yang dipotong 5 x 5 x $5 \mathrm{~cm}$. Volume potongan contoh uji tersebut diperoleh dari pengukuran dimensi panjang, lebar, dan tebalnya. Potongan contoh uji yang telah diukur dimensinya ditimbang untuk mendapatkan berat kering udara. Besarnya kerapatan dihitung dengan rumus:

Kerapatan $=\frac{\text { Berat contoh uji kering udara }(\mathrm{gr})}{\text { Volume kering udara }\left(\mathrm{cm}^{3}\right)}$

\section{Keteguhan Lentur (MOE)}

Contoh uji yang digunakan untuk pengujian keteguhan lentur adalah balok laminasi dengan ukuran panjang, lebar dan tebalnya secara berturut-turut $50 \mathrm{~cm} \mathrm{x} 8 \mathrm{~cm}$ x $18 \mathrm{~cm}$. Pengujian dilakukan menggunakan alat UTM (Universal Testing Machine) dengan dua titik beban. tahapan pengujian 
keteguhan elastisitas menurut JAS 23:2003 meliputi:

a. Pengukuran panjang, lebar dan tebal sampel material.

b. Persiapan posisi material pada penyangga.

c. Pemberian beban pada bagian pusat material uji dengan kecepatan 10 $\mathrm{mm} / \mathrm{menit}$.

d. Mencatat defleksi dan beban.

Persamaan rumus perhitungan modulus elastisitas dapat ditulis sebagai berikut :

$$
\mathrm{MOE}=\frac{\Delta \mathrm{PL}^{3}}{4 \Delta \mathrm{y} \mathrm{h}^{3}}
$$

Keterangan :

$\mathrm{P}=$ beban maksimum pada saat kayu rusak (kgf)

$\mathrm{L} \quad=$ jarak sangga $(\mathrm{cm})$

$\Delta \mathrm{y} \quad=\operatorname{defleksi}(\mathrm{cm})$

$\Delta \mathrm{P} \quad=$ selisih antara beban atas dan bawah (kgf)

$\mathrm{b} \quad=$ lebar contoh uji $(\mathrm{cm})$

$\mathrm{h} \quad=$ tebal contoh uji $(\mathrm{cm})$

\section{Keteguhan Lengkung (MOR)}

Teknik pengujian yang dilakukan sama dengan teknik pengujian pada keteguhan lentur balok laminasi. Pengujian keteguhan lentur dilakukan untuk mengetahui ukuran kemampuan benda untuk menahan beban lentur maksimum sampai saat benda tersebut mengalami kerusakan (Sari, 2011).

Nilai MOR dihitung dengan menggunakan persamaan :

$$
\mathrm{MOR}=\frac{3 \mathrm{PL}}{2 \mathrm{bh}^{2}}
$$

Keterangan :

$\mathrm{P}=$ beban maksimum pada saat kayu rusak (kgf)

$\mathrm{L} \quad=$ jarak sangga $(\mathrm{cm})$

$\mathrm{b} \quad=$ lebar contoh uji $(\mathrm{cm})$

$\mathrm{h} \quad=$ tebal contoh uji $(\mathrm{cm})$

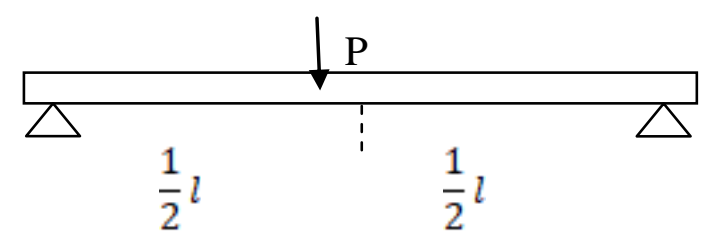

Gambar 3. Proses uji keteguhan lentur dan keteguhan lengkung

Sonia Somadona, Evi Sribudiani, Ditiya Elsa V/Wahana Forestra: Jurnal Kehutanan Vol 15 No 02/2020 59 


\section{HASIL DAN PEMBAHASAN}

\section{Sifat Fisis}

Sifat fisis balok laminasi meliputi kadar air, dan kerapatan dapat dilihat pada tabel 2 dan 3 dibawah ini :

Tabel 2. Hasil Pengujian Kadar Air Balok Laminasi Berdasarkan Berat Labur dan Jenis Lapisan.

\begin{tabular}{|l|l|l|l|l|}
\hline \multirow{2}{*}{$\begin{array}{c}\text { Jenis } \\
\text { Susunan }\end{array}$} & \multicolumn{3}{|c|}{ Berat Labur } & $\begin{array}{c}\text { Rata-Rata } \\
\text { KA Jenis } \\
\text { Susunan (\%) }\end{array}$ \\
\cline { 2 - 5 } & A1 & A2 & A3 & \\
\hline P1 & 7,898 & 7,840 & 8,681 & 8,1402 \\
\hline P2 & 6,1613 & 5,757 & 7,476 & 6,4648 \\
\hline P3 & 4,1447 & 5,636 & 7,306 & 5,6956 \\
\hline P4 & 5,5343 & 4,853 & 6,661 & 5,6829 \\
\hline P5 & 5,663 & 5,298 & 6,352 & 5,7712 \\
\hline P6 & 7,362 & 7,055 & 7,546 & 7,3212 \\
\hline $\begin{array}{l}\text { Rata- } \\
\text { Rata KA } \\
\text { Berat } \\
\text { Labur }\end{array}$ & 6,1274 & 6,0733 & 7,3372 & \\
\hline
\end{tabular}

Hasil pengujian kadar air pada balok laminasi baik berdasarkan berat labur dan jenis lapisan berkisar antara 4,14-8,86 \% dimana hasil tersebut menunjukan kadar air balok lamisi yang dibuat sudah sesuai standar yang digunakan dimana mempersyaratkan dasar air adalah maksimal $12 \%$. Rendahnya kadar air balok laminasi yang dihasilkan dikarenakan bahan baku kayu yang digunakan untuk membuat balok laminasi ini memiliki kadar air yang rendah $(<12 \%)$ dengan kata lain dalam kondisi kering udara sehingga ketika dibuat menjadi balok laminasi, kadar air tidak besar. Kadar air merupakan salah satu faktor yang mempengaruhi kualitas perekatan. Kadar air yang tinggi akan menghalangi masuknya perekat ke dalam rongga sel kayu sehingga keteguhan rekatnya akan menurun. Berdasarkan hasil sidik ragam diperoleh bahwa interaksi antara berat labur dan jenis lapisan berpengaruh tidak nyata terhadap kadar air balok laminasi

\section{Tabel 3. Hasil Pengujian Kerapatan Balok Laminasi Berdasarkan Berat Labur dan Jenis Lapisan.}

\begin{tabular}{|c|c|c|c|c|}
\hline \multirow{2}{*}{$\begin{array}{c}\text { Jenis } \\
\text { Susunan }\end{array}$} & \multicolumn{3}{|c|}{ Berat Labur } & \multirow{2}{*}{$\begin{array}{c}\text { Rata-Rata } \\
\text { Kerapatan } \\
\text { Jenis } \\
\text { Susunan } \\
\left(\mathrm{gr} / \mathrm{cm}^{3}\right) \\
\end{array}$} \\
\hline & A1 & A2 & A3 & \\
\hline P1 & 0,3833 & 0,4233 & 0,4167 & 0,4078 \\
\hline $\mathrm{P} 2$ & 0,5 & 0,4933 & 0,4833 & 0,4922 \\
\hline P3 & 0,39 & 0,41 & 0,42 & 0,4067 \\
\hline $\mathrm{P} 4$ & 0,42 & 0,4133 & 0,4267 & 0,4200 \\
\hline P5 & 0,4833 & 0,47 & 0,5067 & 0,4867 \\
\hline P6 & 0,4267 & 0,4633 & 0,46 & 0,4500 \\
\hline $\begin{array}{l}\text { Rata- } \\
\text { Rata } \\
\text { kerapatan } \\
\text { berat } \\
\text { labur }\end{array}$ & 0,4339 & 0,4456 & 0,4522 & \\
\hline
\end{tabular}


Kualitas balok laminasi salah satunya dipengaruhi oleh bahan baku lamina penyusunnya, sehingga berat jenis lamina penyusun balok laminasi juga dapat mempengaruhi kerapatan dari balok laminasi tersebut. Balok laminasi P2 memiliki kerapatan tertinggi diduga karena balok laminasi P2 tersusun dari lamina kayu meranti merah yang memiliki berat jenis lebih tinggi dari lamina kayu akasia yang terdapat pada balok laminasi P1. Hal ini sesuai dengan Bowyer et al (2003) juga menyatakan bahwa perbedaan nilai kerapatan dipengaruhi oleh jenis lamina, tebal dinding sel, kadar air dan proses perekatan. Hasil kerapatan juga didapat bahwa balok laminasi yang dibuat termasuk kelas kuat IV. Sehingga kayu yang dibuat tidak cocok untuk penggunaan struktural. Berdasarkan hasil sidik ragam diperoleh bahwa interaksi antara berat labur dan jenis lapisan berpengaruh tidak nyata terhadap kerapatan balok laminasi.

Kerapatan balok laminasi dengan berat labur yang berbeda menunjukan bahwa semakin tinggi berat labur maka semakin tinggi pula kerapatan yang dihasilkan, hal ini diduga karena bidang rekat kayu ditutupin oleh perekat yang diberikan dan juga menambah berat balok laminasi. Hal ini sesuai dengan penelitian Abdurachman dan Hadjib (2005) yang menyatakan bahwa pembuatan papan lamina dengan penambahan perekat akan meningkatkan berat papan tersebut. Semakin berat papan lamina akan menghasilkan nilai kerapatan yang tinggi.

\section{Sifat Mekanis}

Sifat mekanis meliputi sifat MOE dan MOR, hasil pengujian dapat dilihat pada tabel 4 dan 5 berikut :

Tabel 4. Hasil Pengujian MOE Balok Laminasi Berdasarkan Berat Labur dan Jenis Lapisan.

\begin{tabular}{|l|l|l|l|l|}
\hline \multirow{2}{*}{$\begin{array}{l}\text { Jenis } \\
\mathrm{n}\end{array}$} & \multicolumn{3}{|c|}{ Berat Labura } & Rata-Rata \\
\cline { 2 - 5 } & A1 & A2 & A3 & $\begin{array}{c}\text { MOE Jenis } \\
\text { Susunan } \\
\left(\mathrm{kg} / \mathrm{cm}^{2}\right)\end{array}$ \\
\hline P1 & 1393,86 & 957,14 & 866,59 & 1072,53 \\
\hline P2 & 1368,70 & 2975,05 & 2240,99 & 2194,91 \\
\hline P3 & 2026,67 & 1534,50 & 1327,43 & 1629,53 \\
\hline P4 & 823,87 & 1646,27 & 1818,21 & 1429,45 \\
\hline P5 & 1878,75 & 1396,88 & 1468,95 & 1582,53 \\
\hline P6 & 1576,95 & 889,12 & 1705,77 & 1390,61 \\
\hline $\begin{array}{l}\text { Rata- } \\
\text { Rata } \\
\text { MOE } \\
\text { Berat } \\
\text { Labur }\end{array}$ & 1511,47 & 1566,49 & 1571,32 & \\
\hline
\end{tabular}


Nilai MOE terendah balok laminasi terdapat pada perlakuan P1 dan tertinggi pada perlakuan P2. Hal ini di duga dikarenakan kerapatan balok laminasi P1 juga paling rendah dan kerapatan P2 yang paling tinggi. Hal ini sesuai dengan Walker (1993), kekuatan kayu dipengaruhi oleh beberapa faktor salah satunya adalah kerapatan. Semakin tinggi kerapatan maka kekuatan kayu akan semakin meningkat.

Nilai MOE balok laminasi yang dibuat dapat dilihat bahwa semakian besar labur yang diberikan maka semakin tinggi nilai MOE. Hal ini diduga karena bidang rekat pada balok laminasi tertutupi oleh perekat. Hal ini sesuai dengan penelitian Cahyadi, dkk (2012) yang menyimpulkan bahwa nilai MOE balok laminasi semakin tinggi dengan bertambahnya berat labur perekat.akan tetapi nilai MOE balok laminasi yang dibuat berdasarkan berat labur dan jenis susunan tidak memenuhi standar yang digunakan yaitu JAS 23:2003 yang mempersyaratkan $75.000 \mathrm{~kg} / \mathrm{cm}^{2}$ hal ini dikarenakan perekat yang digunakan terlalu kental sehingga ketika pelaburan, perekat tidak merata dipermukaan kayu, selain itu juga tidak bisa masuk atau mengalir kedalam pori-pori kayu sehingga perekat tidak mengikat kuat. Berdasarkan hasil sidik ragam diperoleh bahwa interaksi antara berat labur dan jenis lapisan berpengaruh tidak terhadap MOE balok laminasi.

\section{Tabel 5. Hasil Pengujian MOR Balok Laminasi Berdasarkan Berat Labur dan Jenis Lapisan.}

\begin{tabular}{|c|c|c|c|c|}
\hline \multirow{2}{*}{$\begin{array}{c}\text { Jenis } \\
\text { Susunan }\end{array}$} & \multicolumn{3}{|c|}{ Berat Labur } & \multirow[b]{2}{*}{$\begin{array}{c}\text { Rata- } \\
\text { Rata } \\
\text { MOR } \\
\text { Jenis } \\
\text { Susunan } \\
\left(\mathrm{kg} / \mathrm{cm}^{2}\right)\end{array}$} \\
\hline & A1 & A2 & A3 & \\
\hline P1 & 45,07 & 50,02 & 40,50 & 45,19 \\
\hline $\mathrm{P} 2$ & 86,71 & 55,51 & 57,96 & 66,73 \\
\hline P3 & 24,78 & 47,76 & 70,76 & 47,77 \\
\hline P4 & 47,13 & 80,74 & 35,46 & 54,44 \\
\hline P5 & 51,23 & 69,82 & 65,22 & 62,09 \\
\hline P6 & 49,53 & 60,15 & 72,64 & 60,77 \\
\hline $\begin{array}{l}\text { Rata- } \\
\text { Rata } \\
\text { MOR } \\
\text { Berat } \\
\text { Labur }\end{array}$ & 50,74 & 60,67 & 57,09 & \\
\hline
\end{tabular}

Sama dengan nilai MOE nilai MOR balok laminasi yang dihasilkan berkisar 24,78-86,71 kg/cm ${ }^{2}$ dimana juga tidak sesuai dengan standar yang digunakan yaitu berkisar $300 \mathrm{~kg} / \mathrm{cm}^{2}$. Hal ini dikarenakan pengempaan yang tanpa tekanan yang kuat, hanya menggunakan klem. Selain itu juga perekat 
styrofoam yang digunakan memiliki kekentalan yang tinggi sehingga masuk kedalam pori-pori kayu. Berdasarkan hasil sidik ragam diperoleh bahwa interaksi antara berat labur dan jenis lapisan berpengaruh nyata terhadap MOR balok laminasi.

Nilai MOR pada balok laminasi ini dapat dilihat bahwa nilai rata-rata terendah pada perlakuan P1 dan rata-rata tertinggi pada perlakuan P2. Hal ini diduga dikarenakan perbedaan kerapatan lamina yang digunakan. Semakin tinggi kerapatan maka semakin tinggi kekuatan kayu tersebut. Sedangkan pada perlakuan berat labur nya nilai rata-rata MOR terendah pada perlakukan A1 dan tertinggi pda perlakuan A2 dan turun kembali pada perlakuan A3. Hal ini menunjukan tidak semakin besar berat labur maka nilai MOR juga semakin meningkat. Ini diduga karena pelaburan perekat yang kurang rata pada masing-masing ulangan.

Nilai MOE dan MOR balok laminasi kurang baik maka balok laminasi ini tidak cocok untuk keperluan struktural dan juga yang diberikan pembebanan. Papan ini hanya cocok dalam penggunaan keperluan vertikal saja seperti penyekat, dan pengisi pintu rumah.

\section{KESIMPULAN DAN SARAN}

\section{A. Kesimpulan}

Kesimpulan dari penelitian ini adalah hanya kadar air yang sesuai JAS 23:2003 sedangkan kerapatan, MOE dan MOR tidak sesuai standar, sehingga balok laminasi ini tidak cocok untuk penggunaan struktural dan juga diberikan beban yang berat.

\section{B. Saran}

Sebaiknya papan yang dihasilkan digunakan untuk exterior karena bau yang menyengat dari pelarut.

\section{DAFTAR PUSTAKA}

Abdurrachman dan Hadjib N. 2005. Kekuatan dan Kekakuan Balok Lamina dari Dua Jenis Kayu Kurang Dikenal. Jurnal Penelitian Hasil Hutan 23: 87-100.

Bowyer JL, Rubin S, Jhon GH. 2003. Forest Products and Wood Science : An Introduction Fourth edition. United State of Amerika : Lowa State Press.

Cahyadi, D., A. Firmanti, B. Subiyanto. 2012. Sifat fisis dan mekanis bambu 
laminasi bahan berbentuk pelupuh (Zephyr) dengan penambahan metanol sebagai pengganti pengencer perekat. Permukiman Vol.7 No.1: 1-4

Japan Plywood Inspection Corporation. 2003. Japanese Agricultural Standard for Glued Laminated Timber no 234. Tokyo: JPIC.

Kusuma, Ridho Anggara. 2014. Kualitas Balok Laminasi dari Kayu Sengon (Paraserienthes falcataria $(L)$ Nielsen) dan Kayu Mernati Merah (Shorea leporsula. Miq) dengan perlakuan jumlah lapisan dan berat labur perekat. [Skripsi]. Universitas Sumatera Utara. Medan

Pandit IKN dan Dani K. 2008. Sifat Kayu Sebagai Bahan Baku dan Ciri Diagnostik Kayu Perdagangan Indonesia. Bogor: Centium.

Pusat Penelitian dan Pengembangan Hasil Hutan. 2008. Petunjuk Praktis SifatSifat Dasar Jenis Kayu Indonesia $A$ Handbook of Selected Indonesian Wood Species. Indonesiam Sawmill and Woodworking Association (ISWA) dan International Tropical Timber Organitation (ITTO).

Sari, Rima Jentika Permata. 2011. Karakteristik Balok Laminasi dari Kayu Sengon (Paraserianthes falcataria (L.) Nielson), Manii (Maesopsis eminii Willd.), dan Akasia (Acacia mangium Engl.).
Bogor. Skripsi : Institut Pertanian Bogor.

Walker, J. C. F. 1993. Primary wood processing principle and practice champman and hall. London

Winarno, Heru dan Rully Pujantara. 2015. Pengaruh Komposisi Bahan Pengisi Styrofoam pada Pembuatan Batako Martar Semen Ditinjau dari Karakteristik dan Kuat Tekan. Jurnal Scientific Pinisi Vol.1 No.1. 